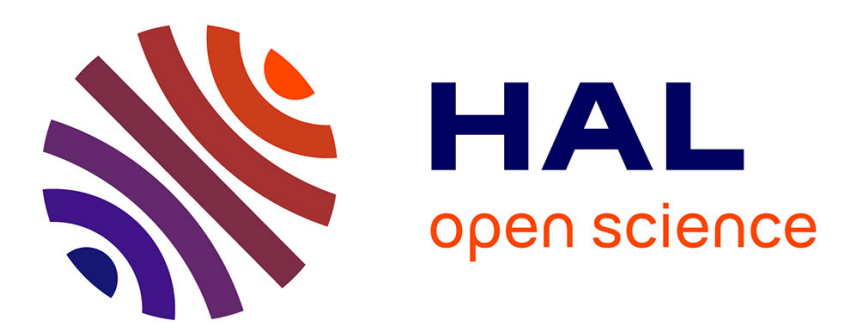

\title{
Diversity of forage system work and adoption of intensive techniques in dairy cattle farms of Amazonia
}

\author{
Nathalie Hostiou, B. Dedieu
}

\section{To cite this version:}

Nathalie Hostiou, B. Dedieu. Diversity of forage system work and adoption of intensive techniques in dairy cattle farms of Amazonia. Agronomy for Sustainable Development, 2009, 29 (4), pp.535-544. 10.1051/agro/2009012 . hal-00886510

\section{HAL Id: hal-00886510 https://hal.science/hal-00886510}

Submitted on 1 Jan 2009

HAL is a multi-disciplinary open access archive for the deposit and dissemination of scientific research documents, whether they are published or not. The documents may come from teaching and research institutions in France or abroad, or from public or private research centers.
L'archive ouverte pluridisciplinaire HAL, est destinée au dépôt et à la diffusion de documents scientifiques de niveau recherche, publiés ou non, émanant des établissements d'enseignement et de recherche français ou étrangers, des laboratoires publics ou privés. 


\title{
Diversity of forage system work and adoption of intensive techniques in dairy cattle farms of Amazonia
}

\author{
N. Hostiou ${ }^{1,2 *}$, B. DEDIEU ${ }^{1}$ \\ ${ }^{1}$ INRA, National Institute for Agricultural Research, UMR 1273 Metafort, 63122 Saint Genès Champanelle, France \\ ${ }^{2}$ Present address: INRA UMR 1273, UMR Métafort, 63122 Saint Genès Champanelle, France
}

(Accepted 14 April 2009)

\begin{abstract}
Forest ecosystems of Brazilian Amazonia are cleared to allow livestock production. Deforestation contributes significantly to climate change and losses of biodiversity. Degradation by scrubs reduces pasture productivity after a few years, thus leading farmers to deforest new areas. For this reason, sustaining cultivated pastures is of major importance for cattle farms. Intensive pasture management techniques have been proposed to the farmers, with little success so far. Our hypothesis is that these techniques are not implemented by farmers due to weak work organisation. Here, we assessed the diversity of forage system work of dairy farms in a municipality on the Transamazon Highway. We analysed factors explaining the adoption of intensive pasture management techniques. We monitored seven dairy farms, with a specific work assessment approach to build synthetic qualification variables and an interview of 29 dairy farmers to characterise the diversity of forage system work. Our results show four tasks related to their technical content: pasture maintenance, renovation, land maintenance and exceptional work. The total duration of work is variable, from 17 to 278 days per year, depending on the technical management choices. Some farmers are autonomous in carrying out the work, but in several cases, wage workers may contribute significantly, from 33 to $100 \%$. We identified five types of forage system work. They oppose very simplified technical management carried out in autonomy by the family workforce to intensive techniques based on a high level of delegation to permanent wage workers. The results show that forage system work is related to the technical management choices and distribution of work between farmers and permanent wage workers. Forage system work also depends on the amount of work dedicated to the dairy herd, the role of milk in the farm, and the weight of other farming and non-farming activities. Finally, intensive pasture management techniques are linked to a high quantity of work with pasture maintenance, hired permanent workers and specialised dairy farms.
\end{abstract}

forage system / work organisation / innovation / livestock farming systems

\section{INTRODUCTION}

More intensive techniques to manage livestock systems need to be developed across the world to reduce the degradation of natural ecosystems (Steinfeld et al., 2006). This is a key concern in Brazilian Amazonia, where cattle raising is subject to heated debate because of its significant contribution to deforestation associated with climate change, and losses of biodiversity and carbon (Fearnside, 2005). Since the 1970s, more than 60 million hectares of pasture have been established after cutting and burning the forest (Fearnside, 2005). Pastures are not sustainable owing to the development of herbaceous and ligneous weeds (Vosti et al., 2002) on the plots once established. After a few years, farmers are compelled to abandon the area and to develop a new one in the forest area. The degradation process induces environmental consequences resulting

* Corresponding author: nhostiou@clermont.inra.fr from deforestation of the largest forest in the world, technical consequences with low herd performances and low economic results for the tropical livestock farming system.

Innovative techniques were developed by the Brazilian Amazonia research and development organisations in order to maintain pasture sustainability (Serrão, 1992). The "intensive pattern" proposes a forage management pattern based on the cutting of weeds during the rainy season, regular followup of the state of the plots throughout the year and nonestablishment of new pasture. Amazonian farmers, however, and notably dairy farmers, seem reluctant to adopt these intensive techniques to manage their forage system (Rueda et al., 2003). Pasture management for dairy cattle production is typically extensive, with little control of weed invasion, and establishment of new plots in the forest. A number of factors were identified to account for the non-adoption of innovative techniques, such as farm size, economic capacities, level of education and age of farmers, and access to markets (Solano et al., 
Table I. Characteristics of the population of 29 dairy farmers.

\begin{tabular}{lcccccc}
\hline & $\begin{array}{c}\text { Pasture area } \\
\text { (ha) }\end{array}$ & $\begin{array}{c}\text { Farm size } \\
\text { (ha) }\end{array}$ & $\begin{array}{c}\text { No. of dairy } \\
\text { cows }\end{array}$ & $\begin{array}{c}\text { Quantity of milk } \\
\text { (L/year) }\end{array}$ & $\begin{array}{c}\text { AU/ha of } \\
\text { pasture }\end{array}$ & $\begin{array}{c}\text { Quantity of milk } \\
(\mathrm{L} / \text { ha of pasture/year) }\end{array}$ \\
\hline $\begin{array}{l}\text { Average } \\
\text { Standard }\end{array}$ & 64 & 114 & 31 & 18110 & 0.99 & 354 \\
deviation & 44 & 93 & 19 & 11779 & 0.39 & 303 \\
\hline
\end{tabular}

$\mathrm{AU}=$ Animal Unit. One $\mathrm{AU}=\mathrm{a} 450 \mathrm{~kg}$ cow.

2006; Lee et al., 2006; Feder et al., 1985). Several authors have emphasised the importance of labour constraints (Mak, 2001), in particular labour availability in Amazonia (Marenya and Barrett, 2007; Vosti et al., 2002). The techniques proposed are labour-intensive (Rueda et al., 2003) and require a large workforce which family livestock farms do not have (Pichon, 1997). However, considering the work issue only from the workforce availability standpoint does not clearly explain the non-adoption of techniques to improve the forage system management (Hervé et al., 2002; Muchagata and Brown, 2003).

Following Madelrieux and Dedieu's work organisation framework (2008), we consider the tasks linked to the forage system as part of a more complex family farm system. Farmers need to consider the consistency between the technical content of the forage system, the duration and rhythm of these tasks (Hervé et al., 2002), the workforce composition, and the interactions with other tasks. For any given farm, the forage system management can be expressed as a set of tasks to be carried out with a seasonal rhythm, and the workers that are in charge of them, leading to a specific duration and distribution over the year. The forage system work is in time competition with other tasks when carried out partly or totally by the same workers. In the dairy farms of Amazonia, the priority for farmers is to milk the cows daily and sell the milk. Crops, either for self-consumption or for sale, can be time-consuming over a long period and are a weighty factor in the allocation of labour (Carpentier et al., 2000).

While the work issue is often considered a hindrance to the adoption of innovations, there are few studies which link the forage system management to the farmer's work organisation problems. Our hypotheses are that the intensive techniques require considerable work time, specifically during the rainy season, to cut the weeds. Such improved forage systems are to be carried out by permanent workers; they are not very compatible with a reduced permanent workforce and/or mixed cattle crops systems. The aim of this study was to identify the diversity of forage system work on dairy farms, and the factors that give coherence to it, taking account of the competition with other tasks and the workforce availability and distribution.

\section{MATERIALS AND METHODS}

The study was conducted in the municipality of Uruará, a settlement located on the Transamazon Highway. It was organised in two steps. First, we selected a reduced sample of farms to carry out a detailed analysis of the way the farm functioned and organised work. This smaller but well explored sample aimed to build synthetic qualification variables that characterise forage system work and to identify explanatory factors. Following a rapid survey, the second step aimed to characterise diversity of forage system work for the total population of Uruará dairy farmers and to highlight the main explanatory factors. The survey draws on the results of the first step using synthetic description variables supplemented by additional explicatory values which account for identified variation factors.

\subsection{Study area}

Uruará began in the early 1970s as a settlement project in the central-eastern Brazilian Amazon for landless rural families originating from the impoverished Brazilian Northeast (Perz and Walker, 2002). Uruará is characterised by a predominance of small-scale farming systems with an average of 100 ha of land and diversified production systems associating cattle and crops (pepper, coffee, rice). It is a small dairy region with 29 dairy farms located near the city and an annual total production of 730000 litres of milk. As in many parts of Amazonia, there is no dairy industry. Farmers sell their milk directly to the town dwellers using a motorcycle to transport it to town. The cattle consists of herds where zebu cattle (Bos indicus), preferred by the ranchers for meat production, tend to be predominant. The zebu are crossed with dairy breeds (Bos taurus). In Uruará, an average dairy herd totalled 31 dualpurpose cows (Tab. I). Herd management is based exclusively on pasture (64 ha on average). The main pasture species is Brachiaria brizantha. The amount of milk produced is about 18110 litres per herd per year. The level of pasture productivity is quite low, with 0.99 Animal Units per ha of pasture and 354 litres of milk per ha of pasture. The family provide the main part of the workforce. The farms are characterised by a very low level of equipment and mechanisation. These structural characteristics were relatively similar to those observed in other regions of Amazonia (Veiga and Tourrand, 2000).

\subsection{Characterising work involved in the forage system on seven farms}

\subsubsection{Sample}

The sample was designed on the basis of previous studies in the same area (Hostiou et al., 2006). Seven out of the 29 dairy farms were selected to cover various situations, taking into account the forage system management, the combination of economic activities and the workforce composition. The sample 
Table II. Structure, workforce and combination of activities of the reduced sample.

\begin{tabular}{|c|c|c|c|c|c|}
\hline Farm & Pasture size (ha) & Dairy cows & $\begin{array}{c}\text { Quantity of milk } \\
\text { (L/year) }\end{array}$ & Workforce & Combination of activities \\
\hline F1 & 53 & 11 & 5300 & Family & Cattle + crops \\
\hline $\mathrm{F} 2$ & 90 & 14 & 8800 & Family & Cattle + crops \\
\hline F3 & 70 & 33 & 15500 & Family + wage workers & Cattle \\
\hline $\mathrm{F} 4$ & 75 & 45 & 21800 & Family + wage workers & Cattle \\
\hline F5 & 80 & 70 & 51700 & Family + wage workers & Cattle \\
\hline F6 & 16 & 17 & 17200 & Family + wage workers & Cattle + non-agricultural \\
\hline F7 & 32 & 13 & 6000 & Family & Cattle + crops \\
\hline
\end{tabular}

is described in Table II. Pasture area varied considerably from 16 to 90 ha. The number of livestock units was also highly diverse, ranging from about 11 to 70 cows. The quantity of milk produced over the year also varied from 5300 to 51700 litres. Three farms specialised in livestock production. Three others associated livestock farming with crops and one with a nonagricultural activity. Work was carried out only by the family workforce on three farms, and with wage workers on the other four.

\subsubsection{Data collection}

In a situation where nothing was known about work linked to the forage system, our aim was to carry out a detailed analysis of forage system practices and tasks, and their duration and distribution over the year, with attention paid to the major factors that could explain diversity. We also aimed to identify the workforce in charge of them, the distribution of tasks among workers and interactions with the other activities.

The seven farms were monitored monthly with semidirective interviews conducted over one year to collect data on the forage system management, and the herd and pasture productivity (Hostiou et al, 2006). During the monitoring period one visit was specifically devoted to the analysis of work organisation using the Work Assessment method (Dedieu, 1993; Madelrieux and Dedieu, 2008). It aimed to integrate the work dimension into the analysis of how livestock farming systems operate at year level. The interview was designed to characterise the forage system and tasks linked to the crops and herd including their duration, content and period. It also took into account the workers and their time contribution to carry out the tasks. The method distinguishes routine tasks with a daily pattern quantified in hours per day, such as cow milking. The other tasks, which are deferrable and can be postponed within a given period, are termed seasonal tasks, viz. repairing fences, establishing pastures, harvesting, etc. Our forage system tasks fall into the category of seasonal tasks. They are quantified in days per year. The workers are not all equivalent regarding their function in the work group and the way they are remunerated for their work. The method distinguishes a basic group composed of permanent workers for whom livestock farming is predominant in time and income. This can be the farmer or the farming couple. The other workers, e.g., volunteers or wage workers, form the workforce outside the basic group.

\subsubsection{Data analysis}

Data consisted of quantitative information (task duration, number of workers) and qualitative information based on what farmers said about the work organisation and their practices. First, we made a comparative analysis of the data, notably of the work duration and distribution between the basic group and the workforce outside the basic group. Factors that could explain diversity were discussed. Then we related the forage system work data to the duration of the routine work, its distribution between the two categories of workers and to the duration of the seasonal work due to crops. In the third stage we selected relevant qualitative variables to characterise work linked to the forage system, in order to be able to investigate the whole population of dairy farms in a short time, without using a detailed methodology such as the Work Assessment method. To this end, we used the repertory grid method developed by Girard et al. (2008). This method, taken from knowledge engineering, consists of building a series of dichotomic attributes, called here variables, defined by extreme situations encountered in the studied cases, and then identifying intermediate situations, called here modalities. We formalised two or four modalities per variable, each modality having roughly the same frequency. We identified six relevant variables to characterise the forage system work. These concerned the tasks, workforce and periods of work. A list of explanatory factors that can explain the different forage system work was also identified during the monitoring. They concerned the herd, productive performances and combination of economic activities.

\subsection{Diversity of forage system work in Uruará dairy farms}

\subsubsection{Data collection}

A brief interview of the 29 dairy farmers was carried out to analyse the diversity of work tied to the forage systems for the total dairy farmer population. The questionnaire was fully structured and gathered easily accessible information on the six variables that characterised forage system work in the previous phase, and nine supplementary variables characterising elements of the family farm system that relate to forage system work (farm structures, activities, performances). 
Table III. Forage system tasks expressed in number of days per year, work period and quantity of work according to pasture area.

\begin{tabular}{lcccccccc}
\hline Farm & $\begin{array}{c}\text { Pasture } \\
\text { maintenance } \\
(\mathrm{d} / \mathrm{y})\end{array}$ & $\begin{array}{c}\text { Pasture } \\
\text { renovation } \\
(\mathrm{d} / \mathrm{y})\end{array}$ & $\begin{array}{c}\text { Land } \\
\text { maintenance } \\
(\mathrm{d} / \mathrm{y})\end{array}$ & $\begin{array}{c}\text { Exceptional } \\
\text { work }(\mathrm{d} / \mathrm{y})\end{array}$ & $\begin{array}{c}\text { Total } \\
\text { seasonal } \\
\text { work }(\mathrm{d} / \mathrm{y})\end{array}$ & $\begin{array}{c}\text { Work } \\
\text { period }\end{array}$ & $\begin{array}{c}\text { No. of } \\
\text { days/ha of } \\
\text { pasture }\end{array}$ & $\begin{array}{c}\text { Ha of } \\
\text { pasture }\end{array}$ \\
\hline F1 & 17 & 0 & 0 & 0 & 17 & No particular & 0.32 & 53 \\
F2 & 0 & 17 & 20 & 0 & 37 & Dry season & 0.41 & 90 \\
F3 & 22 & 54 & 0 & 60 & 136 & Year-round & 1.94 & 70 \\
F4 & 106 & 27 & 0 & 145 & 278 & Year-round & 3.71 & 75 \\
F5 & 124 & 0 & 30 & 0 & 154 & Rainy season & 1.91 & 80 \\
F6 & 15 & 0 & 14 & 0 & 29 & Rainy season & 0.5 & 16 \\
F7 & 0 & 144 & 56 & 0 & 200 & Dry season & 6.25 & 32 \\
\hline
\end{tabular}

\subsubsection{Data analysis}

We sought to characterise the diversity of work related to the forage system for the total population of Uruará dairy farmers and analyse links with the family farm system. On the basis of the data obtained from the 29 dairy farms, we applied a multifactorial analysis followed by an ascendant hierarchical classification (Escofier and Pagès, 1998). The multiple factorial analysis was selected to allow for the analysis of relationships both within and between groups of active variables: the six forage system work variables being active and the other nine variables referring to the explanatory factors being inactive. These analyses were performed using SPAD v 5.5 software. The factors to differentiate forage system work were identified using their eigenvalue and loading. From ascendant hierarchical classification, five types of forage system work were identified.

\section{RESULTS AND DISCUSSION}

\subsection{Forage system work}

In this section, we present the results provided by the reduced sample, concerning the elementary forage system seasonal tasks, their duration, the workforce mobilised to carry them out, and the interactions with the family farm system.

\subsubsection{Variability of elementary seasonal tasks}

Four types of elementary seasonal tasks were found in relation to their content: pasture maintenance, pasture renovation, land maintenance and exceptional work (Tab. III). Pasture maintenance involved cutting back weeds using a sickle. The number of days spent on the farms varied substantially from 0 to 124 days. This number depended on the area maintained. Three modalities were observed: farmers did not carry out pasture maintenance, some cut the weeds on certain plots, and others on the total pasture area. Pasture renovation was applied by farmers to restore plots of weed-infested pasture. This involved first cutting the weeds then burning off the area and subsequently sowing forage seeds of Brachiaria brizantha. This work was done on four farms and required from 17 to 144 days per year. The high variability observed depended on the area renovated and also on the initial level of weed invasion on the plots. Another type of seasonal work was linked to land maintenance and involved fence repairs, requiring 14 to 30 days per year on four farms. The duration was explained by the amount of fencing to be repaired. Exceptional seasonal work included establishing pasture in the forest area and fencing once the pasture was established. Only two farms were concerned. The quantity of work, 60 to 145 days per year, depended on the area established, i.e., respectively, 5 and 10 hectares. Referring to the intensive pattern recommended by the research Institutes, it involved maintenance of the whole pasture area once a year and no other elementary seasonal task.

\subsubsection{Work period}

Periods for carrying out seasonal work differed among farms. We identified four types of distribution (Tab. III). Farmers with low duration of seasonal tasks did not have a particular time schedule and proceeded according to the time available. Some farmers concentrated their seasonal tasks in the dry season. The pasture renovation tasks must be carried out in that period so that the biomass may dry out and be burnt before the first rains. Seasonal work was also concentrated in the rainy season, as was the case for pasture maintenance, in order to favour grass growth and grass competition with weeds. In the last case, the seasonal work period was spread over the whole year. The intensive pattern entailed a distribution of work that was concentrated in the rainy season.

\subsubsection{Duration of seasonal work}

The seven farms displayed variability regarding the duration of work linked to the forage system work over the year, ranging from 17 to 278 days per year (Tab. III). The variability observed in the number of seasonal work days expressed per hectare of pasture ( 0.32 to 6.25 days/ha/year) was also very high. The literature puts forward three factors to explain this variability: area, equipment and the technical management (Dedieu and Servière, 2001). Our data did not suggest a correlation with pasture area, a result that contrasts with French analyses in livestock farms (Jourdan, 1996). The common low level of equipment was not a way to reduce the volume of seasonal work in opposition to more mechanised livestock 
Table IV. Workforce carrying out forage system work.

\begin{tabular}{lcccc}
\hline Farm & $\begin{array}{c}\text { Total seasonal } \\
\text { forage system } \\
\text { work (d/y) }\end{array}$ & \multicolumn{3}{c}{ Forage system work (d/y) } \\
\cline { 3 - 5 } & 17 & 17 & $\begin{array}{c}\text { Seasonal wage } \\
\text { workers }\end{array}$ & $\begin{array}{c}\text { Permanent wage } \\
\text { workers }\end{array}$ \\
\hline F1 & 37 & 37 & 0 & 0 \\
F2 & 136 & 51 & 0 & 0 \\
F3 & 278 & 186 & 95 & 0 \\
F4 & 154 & 20 & 75 & 0 \\
F5 & 29 & 0 & 0 & 58 \\
F6 & 200 & 200 & 0 & 29 \\
F7 & & & & 0 \\
\hline
\end{tabular}

farms (Dedieu and Servière, 2001). So, the main factor was the technical content of the forage system management (Legarto, 2004). Some farmers carried out only one type of task, such as pasture maintenance, on a limited area. Others applied pasture maintenance practices to the total pasture area, with little or no renovation or exceptional work. Others spent quite a lot of time on renovation or exceptional work.

\subsubsection{Workforce composition}

Seasonal work depended on the workforce composition and on the distribution of work among the categories of workers. We identified two categories: the basic group composed of the farmers, and the workforce outside the basic group composed of permanent or seasonal wage workers (Tab. IV). The distribution of forage system work varied significantly between the farms with situations where the basic group was self-sufficient and others where work was delegated to wage workers; permanent, seasonal or both. The situations we investigated showed the significant contribution of wage workers to work, which varied from $33 \%$ to $100 \%$ of the total seasonal work. Several studies describe the essentially family nature of the workforce (Pichon, 1997), whereas in our observations salaried work tends to take central place in understanding the logic of these family farms (Errington and Gasson, 1996). A similar diversity has been observed in a number of Work Assessment studies (Jourdan, 1996). Extreme situations of delegated work may be observed where livestock farmers are overburdened with work as a result of herd size or diversification of farming activities (Dedieu et al., 1998). In our sample, the intensive pattern was extremely work-intensive. It was associated with a high degree of work delegation to permanent wage workers. By contrast, forage systems practised autonomously by farmers tend to resort to simplified technical formulas.

\subsubsection{Interactions with the family farm system}

The forage system work may be analysed as a component of the overall family farm system consistency, taking into account the duration of daily activities, the categories of workforce in charge of them and the other activities (crops, nonagricultural activity). Daily routine work duration included daily tasks linked to hand-milking, selling milk and gathering herds. It varied from 700 to 3955 hours per year (Tab. V).
It may be done autonomously or with a high contribution of permanent wage workers. The main differences resulted from the number of cows being milked and the time devoted to milk sales. Seasonal work for crops involved a high volume of work on four farms, i.e., more than 83 days per year. The non-agricultural activity of F6 was also time-consuming on a daily basis.

The seven cases highlighted several factors which may explain the forage system work done by the basic group workers in relation to the family farm system, i.e., crops, high daily routine work time or pressure of non-agricultural activities. They induced either a simplified forage system management $(\mathrm{F} 1, \mathrm{~F} 2)$ or an intensive one with a high level of delegation (F5, F6). In the latter cases, where milk productivity, expressed in litres per hectare, and herd size were high, the total duration of work for the forage system also tended to be high in order to assure grass production and utilisation. The dairy activity appeared to be a priority. Decreasing the farmer's direct work implies delegating tasks to permanent wage workers. The size of the basic group was also an explanatory factor. Work pressure on each farmer of the basic group was lesser in couples or father - son groups than for individual farmers. They could devote time to pasture management, mainly to renovation (F7). F3 and F4 increased their pasture area: they required seasonal wage worker contribution, the percentage of it being more significant for F4, as he was the only basic group worker. The Amazonian situation highlights the weight of technical management choices, notably for the forage system, because its variability is considerable, with significant repercussions on time and organisation. In contrast, the buildings, equipment and milking parlour are the features that make a difference in Europe.

\subsubsection{Variables to characterise the forage system work}

From our analysis of the seven farms, we selected six variables as being relevant in characterising the forage system work (Tab. VI). These variables related to the workforce involved in the seasonal tasks, the types of tasks carried out and the work period. For each variable, extreme and intermediate "practices" were identified. We also proposed explanatory variables (Tab. VII). The size of the dairy cattle herd and the quantity of milk produced over the year set the duration of daily routine work. The combination of agricultural and nonagricultural activities highlighted interactions and competition with the forage system work. The productive performances of the pasture area underlined the more or less important role of dairy activity on the farm. We also took into account variables that characterise the farm structure such as pasture area, forest area and number of head of cattle.

\subsection{Diversity of forage system work}

\subsubsection{The statistical analysis}

The eigenvalues and loadings of each factor of the multiple factorial analysis are given in Table VIII. We used the first two 
Table V. Competition with daily routine work and crops to explain interactions with forage system work.

\begin{tabular}{|c|c|c|c|c|c|c|c|c|c|c|}
\hline \multirow[t]{2}{*}{ Farm } & \multirow[t]{2}{*}{$\begin{array}{c}\text { No. of people } \\
\text { in the basic group }\end{array}$} & \multirow[t]{2}{*}{$\begin{array}{c}\text { Total seasonal } \\
\text { work }(\mathrm{d} / \mathrm{y})\end{array}$} & \multicolumn{2}{|c|}{$\begin{array}{c}\text { Forage system } \\
\text { work }(\%)\end{array}$} & \multicolumn{2}{|c|}{$\begin{array}{l}\text { Daily routine } \\
\text { work }(\mathrm{h} / \mathrm{d})\end{array}$} & \multirow[t]{2}{*}{$\begin{array}{c}\text { Quantity of } \\
\text { milk (L/year) }\end{array}$} & \multirow[t]{2}{*}{$\begin{array}{c}\text { No. of } \\
\text { dairy cows }\end{array}$} & \multirow[t]{2}{*}{$\begin{array}{c}\text { Litres of } \\
\text { milk/ha }\end{array}$} & \multirow[t]{2}{*}{$\begin{array}{c}\text { Crops } \\
\text { (days/years) }\end{array}$} \\
\hline & & & $\begin{array}{l}\text { Basic } \\
\text { group }\end{array}$ & $\begin{array}{c}\text { Wage } \\
\text { workers }\end{array}$ & $\begin{array}{l}\text { Per person of the } \\
\text { basic group }\end{array}$ & $\begin{array}{c}\text { Wage } \\
\text { workers }\end{array}$ & & & & \\
\hline F1 & 1 & 17 & 100 & 0 & $6 \mathrm{~h} 30$ & 0 & 5300 & 11 & 66 & 111 \\
\hline F2 & 1 & 37 & 100 & 0 & $4 \mathrm{~h} 30$ & 0 & 8800 & 14 & 122 & 83 \\
\hline F3 & 2 & 136 & 37 & 63 & $2 \mathrm{~h} 50$ & 0 & 15500 & 33 & 460 & 0 \\
\hline F4 & 1 & 278 & 67 & 33 & $5 \mathrm{~h} 50$ & 0 & 21800 & 45 & 210 & 108 \\
\hline F5 & 1 & 154 & 13 & 87 & $3 \mathrm{~h} 30$ & $7 \mathrm{~h} 30$ & 51700 & 70 & 640 & 0 \\
\hline F6 & $0 *$ & 29 & 0 & 100 & 0 & $1 \mathrm{~h} 45$ & 17200 & 17 & 1200 & 0 \\
\hline F7 & 2 & 200 & 100 & 0 & $2 \mathrm{~h}$ & 0 & 6000 & 13 & 183 & 98 \\
\hline
\end{tabular}

* F6 has a full-time non-agricultural activity.

Table VI. The six variables used to characterise the forage system work, and their modalities (the number of farms per modality).

\begin{tabular}{|c|c|}
\hline Variables & Modalities (number of farms) \\
\hline \multirow[t]{3}{*}{ Workforce } & 1- Forage system work is carried out only by the basic group (3) \\
\hline & 2- Forage system work is delegated partially to seasonal wage workers (2) \\
\hline & 3- Forage system work is delegated partially to permanent and seasonal wage workers (2) \\
\hline \multirow[t]{3}{*}{ Type of pasture maintenance } & 1- No pasture maintenance (2) \\
\hline & 2- Cutting back weeds on a small area (3) \\
\hline & 3- Cutting back weeds over the whole pasture area (2) \\
\hline \multirow[t]{2}{*}{ Type of pasture renovation } & 1- No pasture renovation (3) \\
\hline & 2- Pasture renovation (4) \\
\hline \multirow[t]{2}{*}{ Type of land maintenance } & 1- No fencing repair (3) \\
\hline & 2- Fencing repair (4) \\
\hline \multirow[t]{2}{*}{ Type of exceptional seasonal work } & 1- No exceptional seasonal work (5) \\
\hline & 2- Exceptional seasonal work (2) \\
\hline \multirow[t]{4}{*}{ Work period over the year } & 1- No particular period (1) \\
\hline & 2- Seasonal work carried out all year (2) \\
\hline & 3- Seasonal work carried out in the dry season (2) \\
\hline & 4- Seasonal work carried out in the rainy season (2) \\
\hline
\end{tabular}

Table VII. The nine variables used to explain work relating to the forage system.

\begin{tabular}{|c|c|c|}
\hline $\begin{array}{l}\text { Types of } \\
\text { variables }\end{array}$ & Variables & \\
\hline \multirow{3}{*}{ Structure } & SUPA & Pasture area \\
\hline & SUFO & Forest area \\
\hline & ВOTO & No. of heads of cattle \\
\hline \multirow{2}{*}{$\begin{array}{l}\text { Daily routine } \\
\text { work }\end{array}$} & VLTO & No. of dairy cows \\
\hline & LIAN & Quantity of milk per year \\
\hline \multirow{4}{*}{$\begin{array}{l}\text { Combination } \\
\text { of activities }\end{array}$} & COMB & 1. No other activity \\
\hline & & 2. Agricultural activity \\
\hline & & 3. Non-agricultural activity \\
\hline & & $\begin{array}{l}\text { 4. Agricultural and non-agricultural } \\
\text { activities }\end{array}$ \\
\hline \multirow{4}{*}{$\begin{array}{l}\text { Productive } \\
\text { performances }\end{array}$} & PRPA & Quantity of milk per ha of pasture \\
\hline & UAEA & Stocking rates per ha of pasture \\
\hline & MILK & 1. Milk production over a specific period \\
\hline & & 2. Milk production over the whole year \\
\hline
\end{tabular}

factors (loadings 26.99 and $25.16 \%$, respectively) to explain the diversity of work linked to the forage system. The first factor concerned variables of the forage seasonal tasks carried out and the work period (Fig. 1). It discriminated farms according to their "proximity" to the intensive pattern. At one end, the analysis pointed to forage system tasks that were closely related to the intensive pattern. It was defined by the cutting of weeds over the whole grazing area exclusively during the rainy season. At the other extreme, we found a type of forage management based on different seasonal tasks. Farmers restricted weed cutting to some plots, carried out pasture renovation and established new pastures in the forest area. Work was done during the rainy and dry seasons according to task types. The second factor contrasted dairy farms according to the delegation of forage system tasks to wage workers and the complexity of the forage system management. At one end, seasonal work was carried out autonomously by the basic group. Farmers simplified their forage management. At the other end, forage system work was partially delegated to seasonal wage workers. Farmers concentrated a high volume of work, notably exceptional work, during the dry season.

\subsubsection{Five types of forage system work}

Five types of forage system work were identified from the ascendant hierarchical classification (Fig. 1). Each type was 


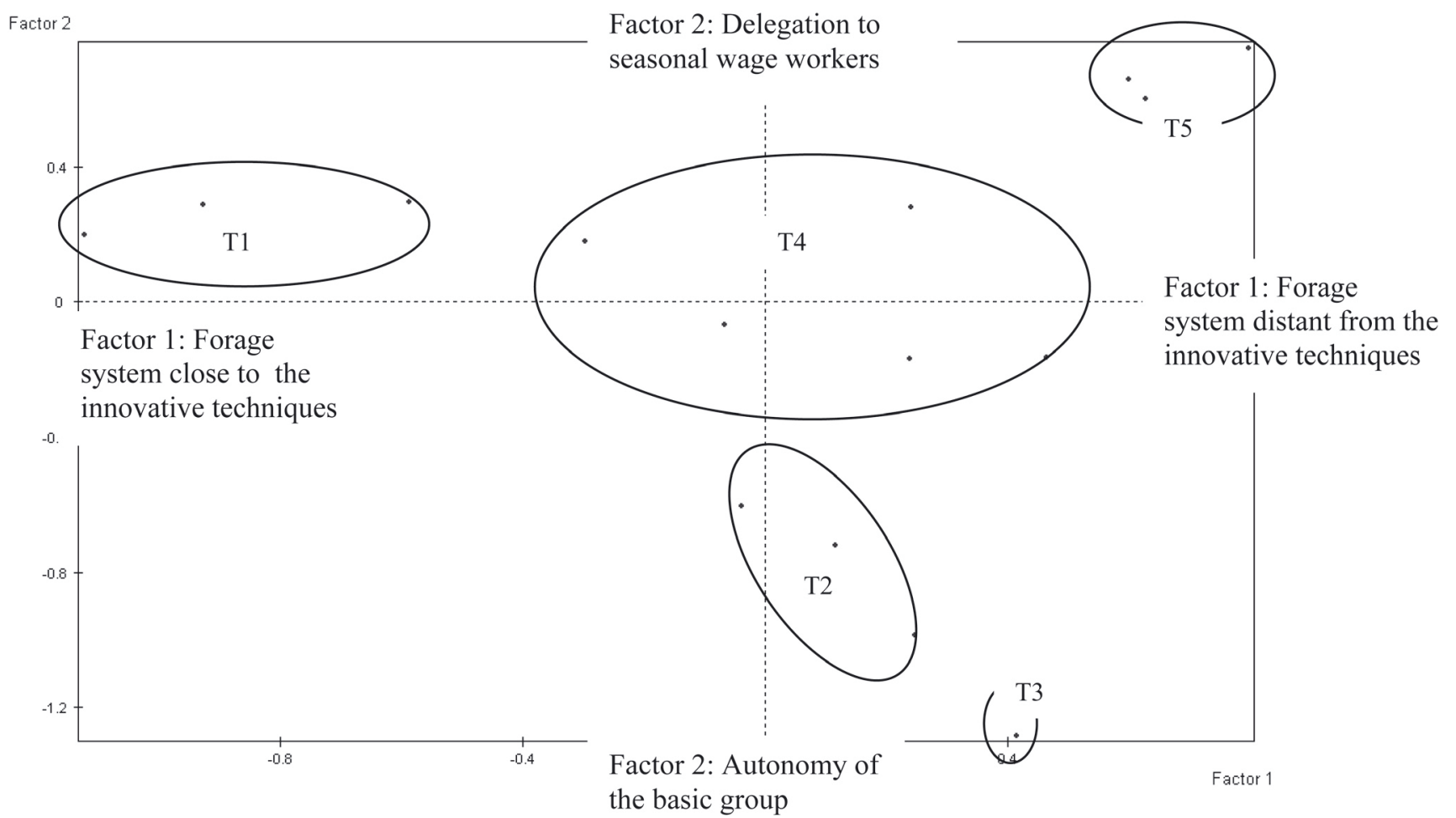

Figure 1. Distribution of farms (circles T1 to T5) on factors 1 and 2 of the multiple factorial analysis. The first two factors were used to explain the diversity of forage system work on dairy farms. The first factor discriminated farms according to their "proximity" to the intensive forage system management pattern. The second factor contrasted dairy farms according to the delegation of forage system tasks to wage workers. The classes issued from ascendant hierarchical classification are the numbered areas.

Table VIII. Loadings and eigenvalues of the 10 factors resulting from the multiple factorial analysis of the 29 farms.

\begin{tabular}{lcc}
\hline Factor & Eigenvalue & Loading $(\%)$ \\
\hline 1 & 0.4499 & 26.99 \\
2 & 0.4194 & 25.16 \\
3 & 0.3563 & 21.38 \\
4 & 0.1653 & 9.92 \\
5 & 0.1232 & 7.39 \\
6 & 0.0559 & 3.35 \\
7 & 0.0380 & 2.28 \\
8 & 0.0319 & 1.92 \\
9 & 0.0213 & 1.28 \\
10 & 0.0056 & 0.33 \\
\hline
\end{tabular}

characterised by a specific combination of modalities of the six active variables in the multiple factorial analysis. Information on the types was completed by data concerning the additional explanatory factors (Tab. IX).

- "Maintaining the pasture with permanent wage workers" (T1). On these eight farms, the forage system work was characterised by a single task, i.e., hand-cutting of weeds on each plot of the pasture area (50 ha on average) as recommended by the intensive pattern. The period of work was concentrated during the rainy season, which the farmers considered to favour grass growth. This forage system work required time during the period of pasture maintenance. Therefore, farmers employed wage workers. Owing to the large number of cows to be hand-milked (43 cows for 25278 litres of milk per year), permanent wage workers also carried out part of the daily routine work. The forage system therefore supported an intensive dairy production compared with regional standards (Muchagata and Brown, 2003). This type of management was observed on farms where the pasture area was stabilised due to limited farm forest area ( 7 ha on average).

- "Maintaining pasture according to the availability of the family workforce" (T2). On these six farms, pasture maintenance was limited to a small area. Work was carried out only by the basic group consisting of the farmer, assisted in two of the farms by another family member (spouse or son). There was no specific period for cutting, because seasonal work was done according to the availability of the family workers and to the competition between livestock and crops. Weed control was used to check the development of self-propagating vegetation, a necessity for easier supervision and monitoring of the cows on the plots. In addition to being poorly controlled, productive performances of pastures were low. The livestock activity was small, with 16 dairy cows and 8813 litres of milk per year. The milk was sold during one part of the year, owing to the low number of cows.

- “Autonomous pasture renovation" (T3). On these three farms, the forage system was based on pasture renovation to 
Table IX. Forage system work in relation to explanatory factors.

\begin{tabular}{|c|c|c|c|c|c|c|c|c|c|}
\hline $\begin{array}{l}\text { Types of } \\
\text { forage } \\
\text { system work }\end{array}$ & $\begin{array}{c}\text { Forage } \\
\text { management }\end{array}$ & $\begin{array}{c}\text { Pasture area } \\
\text { (ha) }\end{array}$ & $\begin{array}{c}\text { Forest area } \\
\text { (ha) }\end{array}$ & $\begin{array}{l}\text { No. of } \\
\text { heads }\end{array}$ & $\begin{array}{l}\text { No. of } \\
\text { cows }\end{array}$ & $\begin{array}{l}\text { Quantity of } \\
\text { milk/year }\end{array}$ & $\begin{array}{c}\text { Productive } \\
\text { performance } \\
\text { of pasture }\end{array}$ & $\begin{array}{l}\text { Wage } \\
\text { labour }\end{array}$ & $\begin{array}{c}\text { Combination } \\
\text { of activities }\end{array}$ \\
\hline $\mathrm{T} 1$ & $\begin{array}{c}\text { Pasture } \\
\text { maintenance }\end{array}$ & 50 & 7 & 114 & 43 & 25278 & High & Yes & On some farms \\
\hline $\mathrm{T} 2$ & $\begin{array}{c}\text { Pasture } \\
\text { maintenance }\end{array}$ & 42 & 35 & 38 & 16 & 8813 & Low & No & Yes \\
\hline $\mathrm{T} 3$ & Renovation & 44 & 23 & 41 & 13 & 6692 & Low & No & Yes \\
\hline T5 & $\begin{array}{c}\text { Pasture } \\
\text { maintenance, } \\
\text { renovation, } \\
\text { exceptional work }\end{array}$ & 62 & 54 & 105 & 34 & 19467 & Medium & Yes & No \\
\hline
\end{tabular}

readjust forage resources to herd requirements. When the level of weeds was too high on the plots grazed by the dairy cows, farmers carried out the renovation by cutting the weeds, burning and sowing of Brachiaria. Another task they carried out was fencing repairs. The work period for these tasks was concentrated in the dry season because of their imperative nature. This type of forage system management was observed on farms where the basic group was composed of one person only, the farmer, who did all the work on the pasture on his own with no wage worker. Furthermore, the farmer was engaged in other agricultural activities such as pepper or coffee, which demand a high volume of work. As a consequence, no pasture maintenance task was carried out during the year owing to this competition and the low availability of family workers. These farms were characterised by a small livestock activity (41 head of cattle, 13 cows, 6692 litres of milk per year), and seasonal milk production.

- "Maintaining the pasture through renovation and weeding with the help of wage workers" (T4). On these six farms the forage system management included pasture maintenance on several plots to curtail weed invasion. The workforce also carried out renovation of degraded pastures to increase forage availability when weeds could not be controlled by cutting. Depending on workforce availability and owing to the high cattle numbers and the pasture area that needed maintaining, weed control was carried out throughout the year. Farmers delegated part of the seasonal work to wage workers. The level of dairy production was high, with 22200 litres of milk, but with low productive performances.

- "Extending the pasture area with seasonal wage workers" (T5). On these six farms, the forage system management was based on exceptional seasonal work to extend the grazed area into the forest (54 ha) and setting up fences. The pasture area was also maintained through hand-cutting of weeds and renovation of some degraded plots. It involved work throughout the year. The workforce was composed of family workers and also of seasonal wage workers. The latter were employed according to the availability of the basic group: they could be hired for the different tasks. These farms were characterised by 62 ha of pasture area and a medium volume of milk (19647 L/year), and specialised in cattle rearing.

\subsection{Factors affecting the forage system management}

Our work pointed out that in the study conditions, the choice of the forage system is determining for the amount of work to be done at year level. Hence, farmers had two options: either to simplify the forage system or to delegate work to wage workers. Farms with high expectations regarding their dairy activity, and therefore needing well-maintained pastures, must find a balance by resorting to wage labour, as in these situations the intensive forage system requires a great volume of work. Other farmers opted for a very simplified forage management pattern, limiting the work to be done. Our typology illustrated intermediate situations where the forage system involves renovating the pastures or exceptional work for which employment of seasonal wage workers is imperative, if the permanent workforce is a limiting factor.

Our results corroborated earlier ones from herbivore production systems in France (Jourdan, 1996; Dedieu et al., 1998), which show that technical management choices play a key role in forage system work. We also confirmed that workforce availability, notably the opportunities for delegating tasks outside the basic group, influences technical management choices (Moulin et al., 2001). A relation could thus be established between technical choices and their impact on work duration, the workforce and the definition of priorities among the different tasks (Madelrieux and Dedieu, 2008). The daily routine work appeared in most cases to be a priority over the seasonal forage system work. The fact that the herd gives a direct income from sales of milk and calves may account for this (Solano et al., 2006). Conversely, a given type of forage system management may be explained by competition with the crops or a non-agricultural activity, as these mobilise labour efforts and little deferrable work during the year (White et al., 2005; Fiorelli et al., 2007). Competition with crops explained why pasture was often maintained by renovation of areas degraded by weeds rather than by regular weed control on some 
farms such as type T2 and T3. The work schedule, in such cases, hindered the adoption of innovative techniques to ensure pasture sustainability.

Our observations confirm Netting's study (1993), which shows that family farmers have additional workforce resources. It was clear from our study, in particular in the light of the characteristics of the group " Maintaining pasture with permanent wage workers", that delegation to permanent wage workers is a prerequisite for the development of more intensive forms of forage system management (Errington and Gasson, 1996). This situation implies that available wage labour is crucial to offsetting household labour shortages and to sustaining agricultural diversity over time.

From this in-depth study of a reduced number of farms, representative of existing situations (Hostiou et al., 2006), we produced the first data on work associated with the forage system, and a first hypothesis on the elements that may help describe and explain its diversity. The analysis made for the 29 dairy farms validated the variables and modalities identified in the reduced sample and enabled us to qualify the diversity of situations in the region under study. Uruará was representative of a large number of regions in Amazonia where the main characteristics are diversified production systems, low levels of equipment and sales of milk carried out by the farmers (Veiga and Tourrand, 2000). It should therefore be possible to transpose the variables, the modalities and factors of differentiation of forage system work on a wider scale than our region of study.

\subsection{Changes of forage system}

Our approach provided a means of introducing work organisation aspects into studies on adoption of technical innovations. We may conclude from this study that intensive techniques to manage the forage system such as cutting back weeds, etc., cannot be implemented on dairy farms without a full understanding of the work organisation. To introduce a new technique to improve the livestock system management one needs to consider its impact in terms of tasks, duration, rhythm and distribution and to analyse (1) its implication on workforce distribution and notably on task delegation, and (2) its relations (seasonal competition, priorities) with other tasks, given the workers that are in charge.

Improving the forage system may be a major goal on the way to sustainable farming systems on the Amazonian agricultural frontier. The propositions made need to consider other types of adaptation of the livestock farming system and not solely target the forage system. For example, improving forage management may be accomplished by reducing daily routine work. This may involve introducing mechanised milking and/or organised breeding to achieve better calving periods (Cournut and Dedieu, 2005). A dairy factory could be set up to collect the milk, thereby reducing the time spent daily by the farmers to sell their milk and making time for other work. On these farms, where all the work is done by hand, introducing equipment to maintain pastures would also allow a reduction of the workload. Pooled equipment for pasture could also reduce capital investment for farms with limited economic resources (Rueda et al., 2003). Diversity of forage system work also means that there is no one single path to be followed by farmers to modify their forage system management. Improving ways of managing pastures to promote their sustainability cannot be formalised for an average farm (Solano et al., 2006), and when considering diversity within one region, features such as the basic group composition, level of mechanisation, and occurrence of other time-consuming activities should be included. Hence for T1, one path could be the use of equipment and mechanisation to reduce workloads. For the other farm types, changes should target herd management to organise calving better, and facilitate recruitment of wage workers and introduction of equipment to limit workloads. Our conclusion is that to improve the forage system management at a territorial level, we should take into account the diversity of work organisation at the farm level.

\section{CONCLUSION}

Our study addresses the issue of barriers to adoption of innovative techniques to maintain sustainable forage systems on Amazonian livestock farms, with particular attention to work organisation on the farm. Studies in this field have so far often considered the family workforce as a central limiting factor (Marenya and Barrett, 2007). While much is known about the forage system diversity, its translation in terms of work tasks, types of workforce and work periods has been little formalised (Muchagata and Brown, 2003). Furthermore, interactions and competition between work devoted to the forage area and other work on the farm or outside it, taking account of the available workforce, have remained unexplored. Thus, our initial hypothesis has been validated: the intensive forage system advocated by research to curtail deforestation on livestock farms is highly work-demanding. With limited family members and a high total workload pressure, intensive management of the forage system relies on the recruitment of permanent wage workers. In situations where the family workforce cannot hire wage workers, the forage system must adjust to priority tasks. Such adjustment means simplifying tasks and techniques. Intermediate situations exist, which we have characterised. To understand choices made or plan conditions for technical change, the technical system must take account of work organisation and work duration on the farm. Introducing the analysis of work organisation into research on livestock farming systems means re-examining the reasons why farmers do what they do without limiting their objectives to technical and economic targets only. This leads us to take a new view of the farm in livestock production science: it is not only a technical production unit; it is also a system where economic and technical goals, expectations with regard to quality of life, social and employment networks, and combination of off- and on-farm activities interact to create the organisations we are studying.

Acknowledgements: The authors wish to thank the French Agricultural Research Centre for International Development (CIRAD), the Brazilian Agricultural Research Corporation (Embrapa) and Gérard Sevière from the French Livestock Institute for their contribution to the realisation of this present study. 


\section{REFERENCES}

Carpentier CL., Vosti SA., Withcover J. (2000) Intensified production systems on western Brazilian Amazon settlement farms: could they save the forest? Agr. Ecosyst. Environ. 82, 73-88.

Cournut S., Dedieu B. (2005) Simplification des conduites d'élevage en bovins laitiers, Cahiers Agricultures 14, 541-547.

Dedieu B. (1993) Organisation du travail et fonctionnement d'exploitations d'élevage extensif du Massif Central, in: Landais E. (Ed.), Pratiques d'élevage extensif. Identifier, modéliser, évaluer, INRA, Paris, France, pp. 303-320.

Dedieu B., Servière G. (2001) Organisation du travail et fonctionnement des systèmes d'élevage, in: Institut de l'Élevage, INRA (Ed.), Rencontres Recherches Ruminants, Paris, France, pp. 245-250.

Dedieu B., Chabosseau J.M., Willaert J., Benoit M., Laignel G. (1998) L'organisation du travail dans les exploitations d'élevage : une méthode de caractérisation en élevage ovin du Centre-Ouest, INRA, Et. Rech. Syst. Agr. Dév. 31, 63-80.

Errington A., Gasson R. (1996) The increasing flexibility of the farm and horticultural workforce in england and wales, J. Rural Studies 12 , $127-141$.

Escofier B., Pagès J. (1998) Analyses factorielles simples et multiples, 3rd ed., Editions Dunod, Paris, 284 p.

Fearnside P. (2005) Deforestation in Brazilian Amazonia: history, rates and consequences, Conserv. Biol. 19, 680-688.

Feder G., Just R.E., Ziberman D. (1985) Adoption of agricultural innovations in developing countries: a survey, Econ. Dev. Cult. Changes 33, 255-298.

Fiorelli C., Pailleux J.Y., Dedieu B. (2007) Explaining diversity of livestock-farming management strategies of multiple-job holders: importance of level of production objectives and role of farming in the household, Animal 1, 1209-1218.

Girard N., Duru M., Hazard L., Magda D (2008) Categorising farming practices to design sustainable land-ude management in mountain areas, Agron. Sustain. Dev. 28, 333-343.

Hervé D., Genin D., Migueis J. (2002) A modelling approach for analysis of agro-pastoral activity at the one-farm level, Agr. Syst. 71, $187-206$.

Hostiou N., Tourrand J.F., Huguenin J., Lecomte P. (2006) La diversité de gestion de systèmes fourragers à l'herbe en Amazonie brésilienne : le cas des élevages mixtes lait-viande à Uruará, Fourrages 187, 377-392.

Jourdan A. (1996) Bilan des "Bilans-travail”, in: Institut de l'ÉlevageINRA-ENITA (Eds.), Bilan-Travail dans les exploitations d'élevage, Institut de l'Élevage-INRA-ENITA, France, 29 p.

Lee D.R., Barrett C.B., McPeak J.G. (2006) Policy, technology, and management strategies for achieving sustainable agricultural intensification, Agr. Econ. 34, 123-127.

Legarto J. (2004) La dimension travail sans le choix d'une conduite alimentaire, in: Institut de l'Élevage, INRA (Ed.), Améliorer les conditions de travail en élevage, Rencontres nationales des acteurs de la recherche-développement, Institut de l'Élevage, INRA, France, pp. 107-111.

Madelrieux S., Dedieu B. (2008) Qualification and assessment of work organisation in livestock farms, Animal 2, 435-446.

Mak S. (2001) Continued innovation in a Cambodian rice-based farming system: farmer testing and recombination of new elements, Agr. Syst. 69, 137-149.

Marenya P.P., Barrett C. (2007) Household-level determinants of adoption of improved natural resources management practices among smallholder farmers in western Kenya, Food Policy 32, 515-536.

Moulin C.H., Girard N., Dedieu B. (2001) L'apport de l'analyse fonctionnelle des systèmes d'alimentation, Fourrages 167, 337-363.

Muchagata M., Brown K. (2003) Cows, colonists and trees: rethinking cattle and environmental degradation, Agr. Syst. 76, 797-816.

Netting R.Mc.C. (1993) Smallholders, Householders: Farm Families and the Ecology of Intensive, Sustainable Agriculture, Stanford University Press, Stanford, CA.

Perz S., Walker R. (2002) Household life cycles and secondary forest cover among small farm colonists in the Amazon, World Dev. 30, $1009-1027$.

Pichon F.J. (1997) Settler households and land-use patterns in the Amazon frontier: farm-level evidence from Ecuador, World Dev. $25,67-91$.

Rueda B.L., Blake R.W., Nicholson C.F., Fox D.G., Tedechi L.O., Pell A.N., Fernandes E.C.M., Valentim J.F., Carneiro J.C. (2003) Production and economic potentials of cattle in pasture-based systems of the western Amazon region of Brazil, J. Anim. Sci. 81, 2923-2937.

Serrão E.A.S. (1992) Alternative models for sustainability cattle ranching on already deforested lands in the Amazon, An. Acad. Bras. Ci 64, 98-104.

Solano C., Leon H., Pérez E., Tole L., Fawcett R.H., Herrero M. (2006) Using farmer decision-making profiles and managerial capacity as predictors of farm management and performance in Costa Rica dairy farms, Agr. Syst. 88, 395-428.

Steinfeld H., Gerber P., Wassenaar T., Castel V., Rosales M., de Haan C. (2006) Livestock's long shadow, Environmental issues and options, Rome, FAO.

Veiga J.B., Tourrand J.F. (2000) Produção leiteira na Amazônia oriental, Situação atual e persectivas. Embrapa Amazônia oriental, Belém, Brasil.

Vosti A., Carpentier C.L., Witover J., Valentim J.F. (2002) Agricultural intensification by small-holders in the Western Brazilian Amazon, From deforestation to sustainable land use, International Foof Policy Report, USA.

White D.S., Labarta R.A., Leguia E.J. (2005) Technology adoption by resource-poor farmers: considering the implications of peak-season labor cost, Agr. Syst. 85, 183-201. 